\title{
Trends in Decreasing Disinfection By-Products Formation during Electrochemical Technologies
}

\author{
Djamel Ghernaout ${ }^{1,2^{*}}$, Noureddine Elboughdiri1,3, Abdulaziz Alghamdi ${ }^{4}$, Badia Ghernaout ${ }^{5}$ \\ ${ }^{1}$ Chemical Engineering Department, College of Engineering, University of Ha'il, Ha'il, KSA \\ ${ }^{2}$ Chemical Engineering Department, Faculty of Engineering, University of Blida, Blida, Algeria \\ ${ }^{3}$ Département de Génie Chimique de Procédés, Laboratoire Modélisation, Analyse, et Commande des systèmes, Ecole Nationale \\ d'Ingénieurs de Gabès (ENIG), Rue Omar Ibn-Elkhattab, Gabès, Tunisia \\ ${ }^{4}$ Mechanical Engineering Department, College of Engineering, University of Ha'il, Ha'il, Saudi Arabia \\ ${ }^{5}$ Laboratory of Mechanics (LME), Department of Mechanical Engineering, University of Laghouat, Laghouat, Algeria \\ Email: ^djamel_andalus@hotmail.com
}

How to cite this paper: Ghernaout, D., Elboughdiri, N., Alghamdi, A. and Ghernaout, B. (2020) Trends in Decreasing Disinfection By-Products Formation during Electrochemical Technologies. Open Access Library Journal, 7: e6337.

https://doi.org/10.4236/oalib.1106337

Received: April 19, 2020

Accepted: May 6, 2020

Published: May 9, 2020

Copyright $\odot 2020$ by author(s) and Open Access Library Inc.

This work is licensed under the Creative Commons Attribution International License (CC BY 4.0).

http://creativecommons.org/licenses/by/4.0/

\begin{abstract}
Disinfecting water and wastewater electrochemically is a cost-effective and environmentally friendly alternative for the chemical disinfection. During electrochemical disinfection, the water is passed through an electrolytic cell which is equipped with a set of electrodes. The effectiveness of the process depends upon cell configuration, electrode material, electrolyte composition, microorganism, water flow rate, and current density. One of the main advantages of electrodisinfection is the on-site production of disinfectants; thereby the common drawbacks of chlorination including transportation and storage of hazardous chemicals can be avoided. On the other hand, the high cell voltages due to low electrical conductivity of water and the high capital cost are the main bottlenecks for electrodisinfection. The generation of chlorinated by-products stays the main worry related to electrochemical water treatment processes. This work discusses the main tendencies in dealing with such issues. In some setups, the electrolyte separates the anode and cathode is a proton exchange membrane. This assists to reduce the formation of perchlorate and such conduct is improved in the smallest cell for which the so short contact periods between the electrodes and the water helps to avert the formation of perchlorates when working in a single-pass mode, which becomes a really remarkable point. Other strategies are examined such as developed electrochemical advanced oxidation process, the electroperoxone (E-peroxone) process, which combines ozonation with in situ electro-generation of hydrogen peroxide $\left(\mathrm{H}_{2} \mathrm{O}_{2}\right)$ from cathodic oxygen reduction.
\end{abstract}


Electrochemical processes could be merged with nanotechnologies for better efficiency in dealing with pathogens and pollutants removal. In the next future, a hybrid process combining both techniques would be suggested as a part of treatment train for treating water and wastewater.

\section{Subject Areas}

Chemical Engineering \& Technology

\section{Keywords}

Disinfection, Disinfection By-Products (DBPs), Organic Matter (OM), Hydroxyl Radical, Electroperoxone (E-Peroxone), Nanotechnologies

\section{Introduction}

Disinfection employing electrochemical technologies is beginning to be actually crucial technical dare nowadays [1] [2] [3]. Most of the achievements noticed recently focused on determining the dissimilarities in the disinfection performances obtained among numerous kinds of electrodes [4] [5] [6] [7], which may be employed in such engineering [8] [9] [10] [11]. Many reports worked on averting the generation of disinfection by-products (DBPs) [12] [13] [14] [15] [16]. Some researchers dealt with the design of the electrochemical reactor, which has an extremely fundamental influence on the electrocatalytic conduct of the setup, increasing or decreasing the generation of oxidants [17] [18] [19]. In this context, electrochemical reactors in which the residence period between the electrodes and the water to be disinfected is short could be a good option, since they may participate in avoiding the generation of poisonous species such as chlorate and perchlorate [20] [21] [22] [23] [24]. Such an action plan, which could be realized via employing a single pass of the water to be disinfected across the cell, has been considered as encouraging, even if it is not the definitive manner to deal with such an issue [1] [25]-[30].

Oxidizing chlorides to chlorine is a well-known industrial technique [1] [2] [31] [32] [33] [34]. Chlorine is produced so efficaciously with numerous kinds of electrodes like platinum or mixed metal oxides (MMO) (Equation (1)). While generating chlorine in solution without separation of the anodic and cathodic compartments of the electrochemical setup, chlorine is disproportionated into chloride and hypochlorite (Equations (2) and (3)) [1] [2] [35] [36].

$$
\begin{aligned}
2 \mathrm{Cl}^{-} & \rightarrow \mathrm{Cl}_{2}+2 \mathrm{e}^{-} \\
\mathrm{Cl}_{2}+\mathrm{H}_{2} \mathrm{O} & \rightarrow \mathrm{HClO}+\mathrm{H}^{+}+\mathrm{Cl}^{-} \\
\mathrm{HClO} & \leftrightarrow \mathrm{H}^{+}+\mathrm{ClO}^{-}
\end{aligned}
$$

Such a phenomenon is significant when estimating the anodic oxidation of wastewater contaminated with organic matter $(\mathrm{OM})$ since hypochlorite conducts to faster reduction of OM but generating organo-chlorinated species [37] [38] 
[39] [40] [41]. This is one of the main barriers to such environmental utilizations presently [1] [42] [43] [44].

Ten years ago, it was observed that chlorine was not the last result of the oxidation of chloride using diamond anodes but, with such electrodes, the response persists until the generation of perchlorates, due to the activity of the hydroxyl radicals produced on their surface [1] [45] [46]. It was an extremely difficult obstacle, as the oxidizing performance reached with such electrodes was much bigger and, indeed, they could form other significant oxidants throughout disinfection (such as ozone, peroxocarbonates or peroxophosphates), which could participate to a more performant technique [1] [47] [48] [49] [50].

Therefore, the dissimilarities between the efficiencies of the electrodes are greatly significant [1]. Oxidizing chloride to chlorine can be directly on the surface of the electrode or mediated by hydroxyl radicals [2] [51]. In the case of the MMO electrode, the hydroxyl radicals produced throughout the oxidation of water are rapidly integrated with the metal oxides of the anode to generate transient higher oxidation state oxides. Consequently, the reaction of chlorinated species ends there and only aging of the hypochlorite solution is in charge of the production of small quantities of chlorate, which had been interpreted in terms of complex chemical pathways. Nevertheless, if employing diamond electrodes, hydroxyl radicals do not interact with the surface of the electrode and they are accessible to merge with hypochlorite, following Equations (4) and (5), leading to the production of perchlorates [1].

$$
\begin{gathered}
\mathrm{ClO}^{-}+2^{\bullet} \mathrm{OH} \rightarrow \mathrm{ClO}_{3}^{-}+2 \mathrm{H}^{+}+2 \mathrm{e}^{-} \\
\mathrm{ClO}_{3}^{-}+{ }^{\bullet} \mathrm{OH} \rightarrow \mathrm{ClO}_{4}^{-}+\mathrm{H}^{+}+\mathrm{e}^{-}
\end{gathered}
$$

As a consequence, to avert the generation of this species, it is so crucial to prohibit the contact between the hydroxyl radicals and the hypochlorite [1].

This work discusses the main tendencies in dealing with such issues. In many setups, the electrolyte that separates the anode and cathode is a proton exchange membrane. This assists to reduce the formation of perchlorate and such conduct is improved in the smallest cell for which the so short contact periods between the electrodes and the water helps to avert the formation of perchlorates when working in a single-pass mode, which becomes a really remarkable point. Other strategies are examined such as developed electrochemical advanced oxidation process, the electroperoxone (E-peroxone) process, which combines ozonation with in situ electro-generation of hydrogen peroxide $\left(\mathrm{H}_{2} \mathrm{O}_{2}\right)$ from cathodic oxygen reduction. Electrochemical processes could be merged with nanotechnologies for better efficiency in dealing with pathogens and pollutants removal.

\section{Averting the Generation of Hazardous Chlorates and Perchlorates through Electro-Disinfection with Diamond Anodes}

Isidro et al. [1] worked on the prohibition of the production of chlorates and 
perchlorates. Their action plan adopted is the reduction in the contact period of the electrode with the electrolyte [52] attempting to avert the interactions of hypochlorite with hydroxyl radicals produced on the surface of the diamond anode. They founded their action plan on former remarks. In juxtaposing the efficiency of two commercial cells fabricated by CONDIAS (Itzehoe, Germany) and equipped with the diamond electrodes, they observed that the formation of perchlorate with one of them was minor or completely inexistent. Such conduct was even more unexpected when juxtaposing the cells as they had precisely the identical fundamental design standards. They wanted to deal with such a dare and to interpret the reasons, focusing on the manner of employing diamond electrodes for killing pathogens without generating perchlorates. As mentioned above, such an objective is important since the electrolytic diamond technique in eliminating microorganisms from water is how to bypass the formation of chlorates and perchlorates throughout the method.

Isidro et al. [1] employed a particular kind of commercial cells designed by CONDIAS in two different sizes: the CabECO and the MIKROZON cells (Figure 1). In such setups, the electrolyte that separates the anode and cathode is a proton exchange membrane. This assists to reduce the formation of perchlorate and such conduct is improved in the smallest cell for which the so short contact periods between the electrodes and the water helps to avert the formation of perchlorates when working in a single-pass mode, which becomes a really remarkable point. Isidro et al. [1] established such excellent efficiency and interpreted the dissimilarities noted in the two cells running with the identical wastewater.

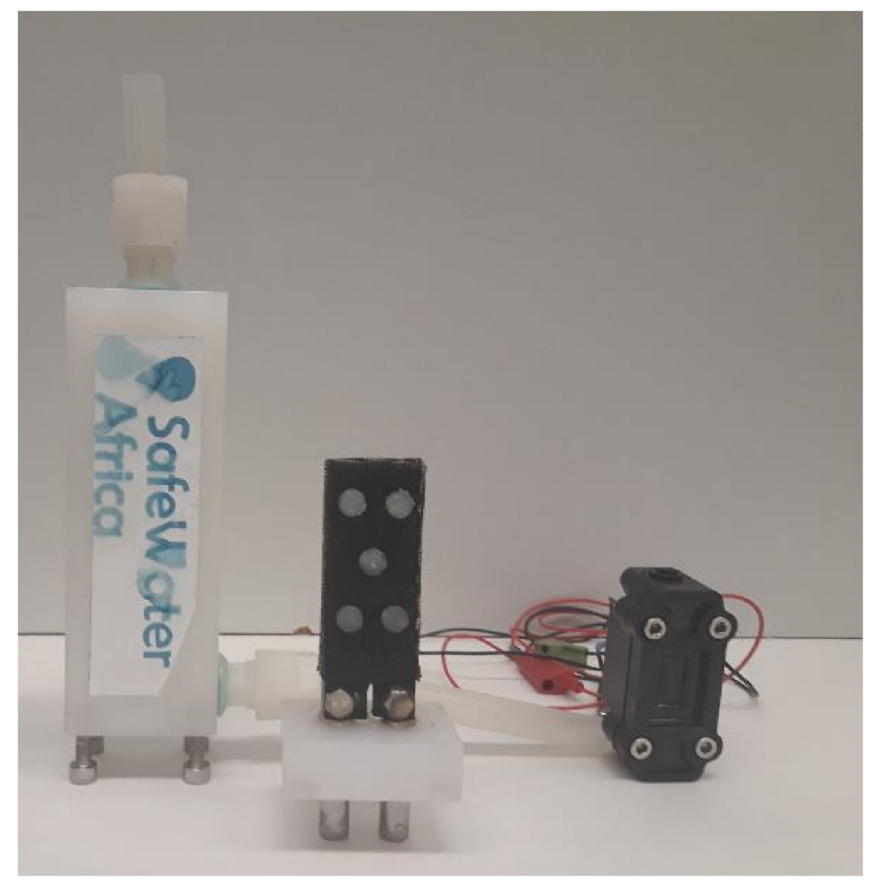

Figure 1. From the left to the right: CabECO (with a detail of its inner part) and MIKROZON cells [1]. 
Despite utilizing a polymer exchange membrane as electrolyte instead of water, devices consisting of membrane electrode assemblies like the commercial cells CabECO and MIKROZON have the potential to be efficaciously employed for disinfecting water. In fact, such setups were designed to generate ozone in low conductivity water. They could eliminate 3 - 5 logs of CFU with electric charges applied as low as $0.04 \mathrm{Ah} / \mathrm{L}$. The higher the charge applied, the higher is the disinfection level attained [1].

\section{Disinfecting Electrochemically Water via Direct and Indirect Oxidation Processes}

Rahmani et al. [53] studied the electrodisinfection of total coliform (TC) and fecal coliform (FC) with an attention on direct and indirect oxidation utilizing a series of anodes (stainless steel (SS)/lead $(\mathrm{Pb}) \mathrm{O}_{2}\left(\mathrm{SS} / \mathrm{PbO}_{2}\right)$, stainless steel, titanium (Ti), platinum ( $\mathrm{Pt}$ ), graphite (GP) and $\mathrm{Pb} / \mathrm{PbO}_{2}$ ). They followed the impact of electrode material, current density (CD), charge passed, initial $\mathrm{pH}$ values, different concentrations of $\mathrm{NaCl}$, total dissolved salts (TDSs), electrical conductivity and energy consumption on technique efficiency. The quantity of in situ produced active chlorine throughout the method below the best circumstances for each anode was observed to be efficacious in eliminating microbes. The disinfection setup was so performant in killing pathogens in occurrence of $0.01 \mathrm{M} \mathrm{NaCl}$. Augmenting CD from 0.16 to $0.5 \mathrm{~mA} / \mathrm{cm}^{2}$ conducted to a reduction of more than $60 \%$ in $\log _{10}$ bacterial load for all electrodes except Pt. Among anodes tried, $\mathrm{SS} / \mathrm{PbO}_{2}$ showed the greatest performance (total demobilization) in $5 \mathrm{~min}$ via implementing $0.01 \mathrm{M} \mathrm{NaCl}$ in $\mathrm{CD}$ of $0.5 \mathrm{~mA} / \mathrm{cm}^{2}$ when charge passed was $>15$ C. The performance of the anodes in demobilizing TC and FC was in the order of $\mathrm{SS} / \mathrm{PbO}_{2}>\mathrm{SS}>\mathrm{Ti}>\mathrm{Pt}>\mathrm{GP}>\mathrm{Pb} / \mathrm{PbO}_{2}$. In spite of the elevated effectiveness of the electrochemical technology in neutralizing TC and FC, indirect oxidation possesses a bigger efficacy thanks to the formation of powerful oxidants like radical hydroxyl and active chlorine (Figure 2 ).

\section{Impacts of $\mathrm{pH}$ and Reactive Oxygen Species on the Generation of Chlorate and Perchlorate during Electrolysis Utilizing Pt/Ti Electrodes}

Jung et al. [54] investigated the properties of chlorate $\left(\mathrm{ClO}_{3}^{-}\right)$and perchlorate $\left(\mathrm{ClO}_{4}^{-}\right)$generation throughout the electrolysis of water carrying chloride ions $\left(\mathrm{Cl}^{-}\right)$. The tests were realized employing an undivided $\mathrm{Pt} / \mathrm{Ti}$ plate electrode (Figure 3) below various $\mathrm{pH}$ circumstances ( $\mathrm{pH} 3.6,5.5,7.2,8.0$ and 9.0). $\mathrm{ClO}_{3}^{-}$ and $\mathrm{ClO}_{4}^{-}$were produced during electrolysis in proportion to the $\mathrm{Cl}^{-}$level. The formation rates of $\mathrm{ClO}_{3}^{-}$and $\mathrm{ClO}_{4}^{-}$below acidic circumstances $(\mathrm{pH} 3.6$ and 5.5) (Table 1) [55] were lower than in alkaline $\mathrm{pH}$ circumstances ( $\mathrm{pH} 7.2,8.0$ and 9.0). Nevertheless, the $\mathrm{pH}$ of the solution did not affect the transformation of $\mathrm{ClO}_{3}^{-}$to $\mathrm{ClO}_{4}^{-}$. The influences of intermediately produced oxidants on the formation of $\mathrm{ClO}_{3}^{-}$and $\mathrm{ClO}_{4}^{-}$were detected utilizing sodium thiosulfate 


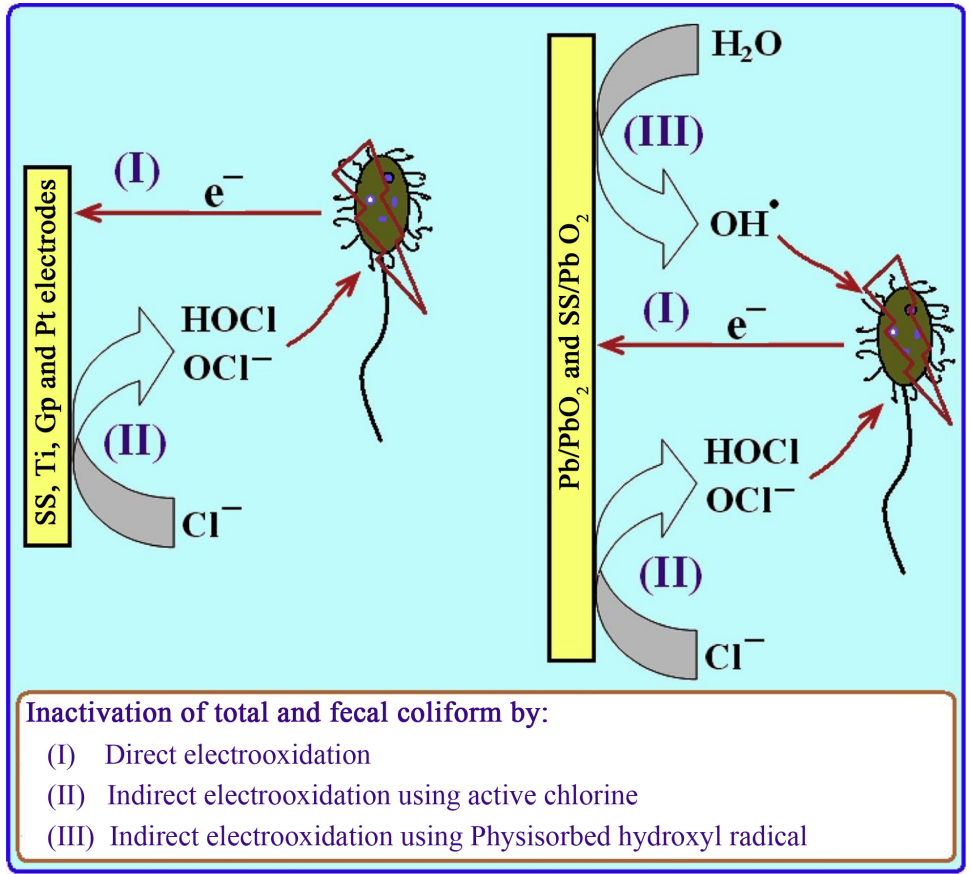

Figure 2. The pathway of TC and FC inactivation by electrodisinfection [53].
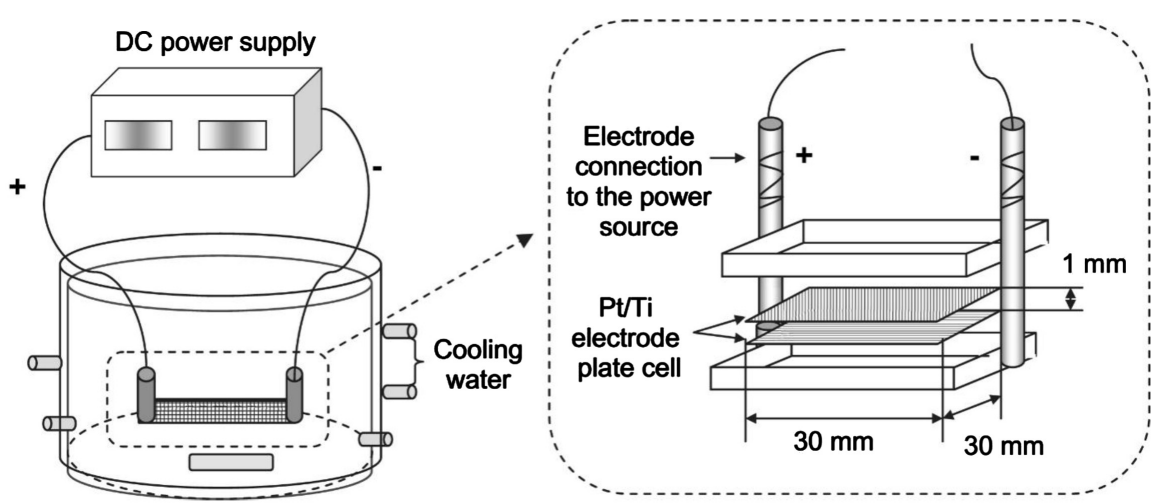

Figure 3. Schematic view of electrolysis device [54].

Table 1. Oxidation power in acidic media of various anode materials used in electrooxidation [55].

\begin{tabular}{ccccc}
\hline $\begin{array}{c}\text { Electrode } \\
\text { Material }\end{array}$ & $\begin{array}{c}\text { Oxidation } \\
\text { Potential }(\mathrm{V})\end{array}$ & $\begin{array}{c}\text { Overpotential } \\
\text { of } \mathrm{O}_{2} \text { Evolution } \\
(\mathrm{V})\end{array}$ & $\begin{array}{c}\text { Adsorption } \\
\text { Enthalpy } \\
\text { of } \mathrm{MO}_{\mathbf{x}}\left({ }^{\circ} \mathrm{OH}\right)\end{array}$ & $\begin{array}{c}\text { Oxidation } \\
\text { Power of the } \\
\text { Anode }\end{array}$ \\
\hline $\mathrm{RuO}_{2}-\mathrm{TiO}_{2}$ & $1.4-1.7$ & 0.18 & Chemisorption of ${ }^{\bullet} \mathrm{OH}$ & \\
$\mathrm{IrO}_{2}-\mathrm{Ta}_{2} \mathrm{O}_{5}$ & $1.5-1.8$ & 0.25 & & \\
$\mathrm{Ti} / \mathrm{Pt}$ & $1.7-1.9$ & 0.3 & \\
$\mathrm{Ti} / \mathrm{PbO}_{2}$ & $1.8-2.0$ & 0.5 & \\
$\mathrm{Ti} / \mathrm{SnO}_{2}-\mathrm{Sb}_{2} \mathrm{O}_{5}$ & $1.9-2.2$ & 0.7 & & $\downarrow$ \\
$\mathrm{p}-\mathrm{Si} / \mathrm{BDD}^{*}$ & $2.2-2.6$ & 1.3 & Physisorption of ${ }^{\bullet} \mathrm{OH}$ & \\
\hline
\end{tabular}

${ }^{*} \mathrm{BDD}$ : Boron-doped diamond. 
$\left(\mathrm{Na}_{2} \mathrm{~S}_{2} \mathrm{O}_{3}\right)$ as the active chlorine scavenger and tertiary butyl alcohol $(t-\mathrm{BuOH})$ as the hydroxyl radical $\left({ }^{\circ} \mathrm{OH}\right)$ (Table 2) [26] [55] [56] scavenger. Electrolysis reactions that implied active chlorine participated dominantly in $\mathrm{ClO}_{3}^{-}$formation (Figure 4). The direct oxidation reaction rate of $\mathrm{Cl}^{-}$to $\mathrm{ClO}_{3}^{-}$was $13 \%$. The - $\mathrm{OH}$ species that were intermediately produced throughout electrolysis were also observed to importantly touch $\mathrm{ClO}_{3}^{-}$and $\mathrm{ClO}_{4}^{-}$formation.

\section{Nanomaterials for Killing Pathogens}

As seen above, chemical technologies of disinfection possess several obstacles and numerous microorganisms have formerly developed resistance versus such traditional methods [57] [58] [59] [60]. Implementing nanomaterials in water treatment and pollutant removal possesses a highly daunting and encouraging future than their conventional counterparts, wiping out restrictions and secondary impacts of classical techniques. Metal oxide nanoparticles, fullerenes, photocatalysts, nanomembranes, and additional similar techniques guarantee a long-term solution for biological contamination of water. Integrating two or more nanomaterials could work as a multipurpose solution to neutralize pathogens as well as dissolved and undissolved impurities. Several of these nanomaterials

Table 2. Thermodynamic formation potentials of several oxidants [26] [55] [56].

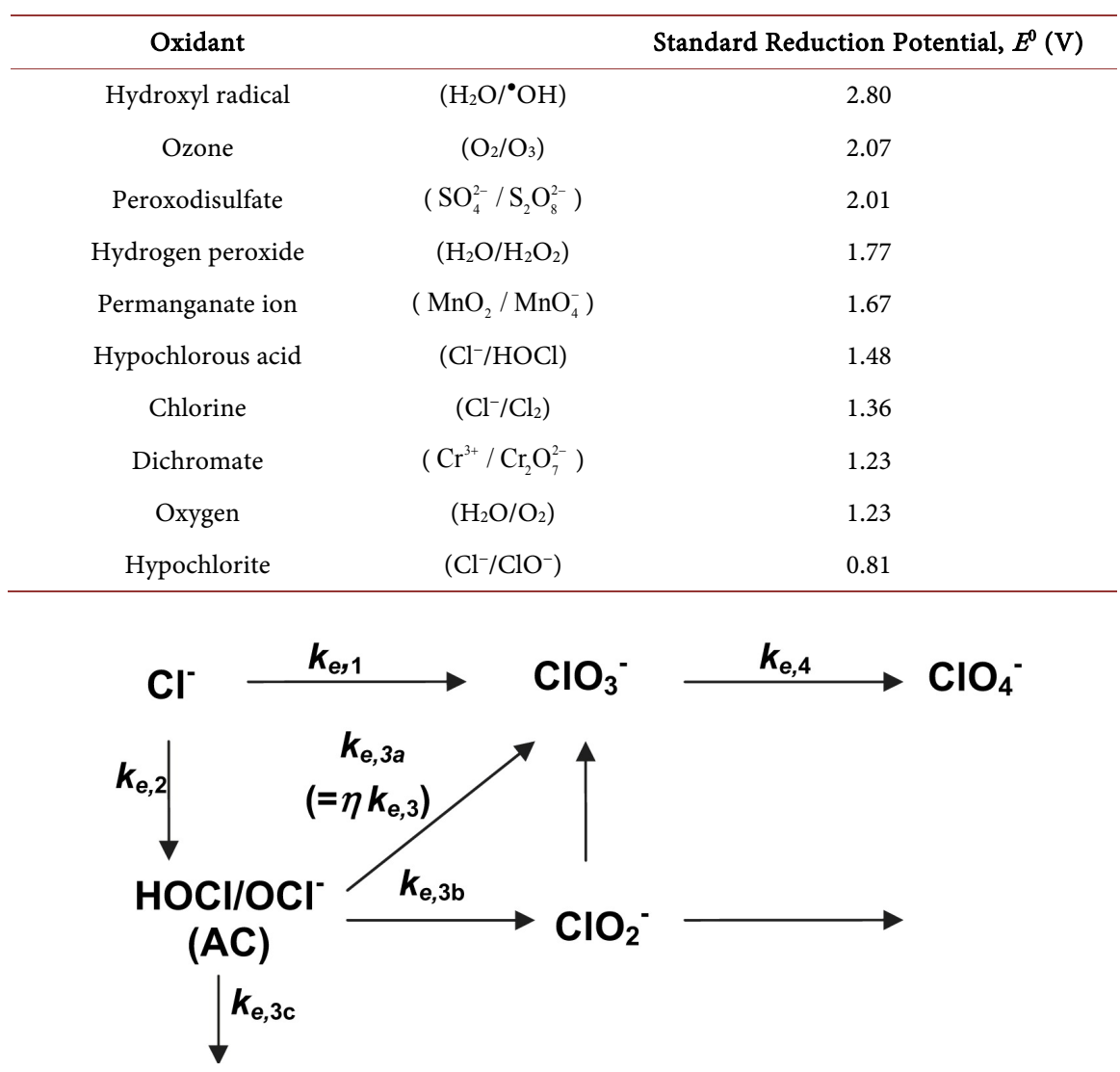

Figure 4. Suggested primary mechanisms of $\mathrm{Cl}^{-}$oxidation to $\mathrm{ClO}_{4}^{-}$ throughout electrolysis [54]. 
possess also increase adsorbent features, which establish new pathways for the development of a hybrid system for water treatment techniques. Many carcinogenic chemicals will be discontinued after their cost-effective establishment as water treatment units. The future of safe drinking water can be thrust upon these

"tiny particles." The tailoring nature of these nanomaterials lets the researchers develop more and more sustainable and robust technology. Nevertheless, every technology arrives with some hurdles. As discussed by Ojha [57], there are numerous worries in the nanotechnological utilizations. Such problems require deeper insight and should be duly dealt with. More and more focus on eco-friendly nanomaterials should be made so as to have a perfect technique to combat the water crisis. Methods should be developed with a small cost of production and fewer chemicals required. Biosynthesis and biopolymers or bionanoparticles can play an important role in this regard. Nanomaterials with the least effect on humans and ecology are still to be designed for using them substantially in daily life. Lab to field applications and the studying effect of these nanoparticles in the living system should be taken care of [57].

\section{Juxtaposing Carbonized and Graphitized Carbon Fiber Electrodes under Flow-Through Electrode System (FES) for Demobilizing Bacteria}

$\mathrm{Ni}$ et al. [61] assessed the disinfection efficiency of a flow-through electrode system (FES) employing numerous carbonized (C1, C2, and C3) and corresponding graphitized (G1, G2, and G3) carbon fiber felt (CFF) electrodes. They analyzed the physicochemical and electrochemical features to determine the dissimilarities among CFFs. Graphitized CFFs (gCFFs) could attain total demobilization of Escherichia coli $(>6 \mathrm{log})$ at the voltage of $3 \mathrm{~V}$ and flux of $120-3600 \mathrm{~L} /\left(\mathrm{m}^{2} \mathrm{~h}\right)$ for high conductivity and chemical stability, while carbonized CFFs (cCFFs) only reached about $1 \log$ removal with apparent carbon corrosion. For the gCFFs, G1 (>6 log removal) with higher conductivity, better graphite structure, and larger surface area (related to fiber diameter and density) depicted better killing potential at the flow rate of $30 \mathrm{~mL} / \mathrm{min}$ than $\mathrm{G} 2(\sim 3 \mathrm{log})$ and $\mathrm{G} 3(\sim 1 \mathrm{log})$. In addition, no regrowth and reactivation of bacteria happened during the storage under visible light illumination after FES treatment. Three parallel FESs with G1 were operated continuously for one week ( $24 \mathrm{~h}$ per day, 7 days) treating the solution with an E. coli concentration ranging from $10^{6}$ to $10^{7} \mathrm{CFU} / \mathrm{mL}$ at the applied voltage of $3 \mathrm{~V}$ and the flow rate of $20 \mathrm{~mL} / \mathrm{min}$. No live bacteria were detected in the effluent of any of these three FESs (Figure 5). In-situ sampling experiments demonstrated that the inactivation of bacteria on anode was the dominant mechanism for FES treatment, which can be attributed to the sequential adsorption, direct-oxidation and desorption process on anode, instead of indirect oxidation by generating chemical oxidants. In addition, hydroxide ion generated from cathode reaction enhanced anode adsorption and inactivation of bacteria by providing alkaline environment. Combining the analysis results of material proper- 
ties and disinfection performance, the gCFF-based FES was suggested to be a low-cost, high-efficiency, and safe alternative for future water disinfection [61].

\section{Electrocoagulation and Electro-Fenton for Demobilizing Microbiota from Urban Wastewater}

Anfruns-Estrada et al. [62] focused on juxtaposing the capability of two types of electrochemical technologies, namely electrocoagulation (EC) [63] [64] [65] [66] [67] and electro-Fenton (EF), to disinfect primary and secondary effluents from urban wastewater treatment plants. They tried heterotrophic bacteria, E. coli, enterococci, Clostridium perfringens spores, somatic coliphages and eukaryotes (amoebae, flagellates, ciliates, and metazoa) as indicator microorganisms. EC with a Fe/Fe cell at $200 \mathrm{~A} / \mathrm{m}^{2}$ and natural $\mathrm{pH}$ reached $>5 \log$ unit removal of $E$. coli and final concentration below 1 bacteria/mL of coliphages and eukaryotes from both effluents in $\sim 60 \mathrm{~min}$, whereas heterotrophic bacteria, enterococci and spores were more resistant. A bigger reduction was attained for the primary effluent, possibly due to the flocs that eliminate a bigger quantity of total organic carbon (TOC), enmeshing more easily the microbiota [68] [69] [70]. EF with a $\mathrm{BDD}$ anode and an air-diffusion cathode that generates $\mathrm{H}_{2} \mathrm{O}_{2}$ on site was first realized at $\mathrm{pH} 3.0$, with huge or even complete neutralization of pathogens for 30 min. A more efficacious microorganism reduction was obtained as juxtaposed to EC because of ${ }^{\bullet} \mathrm{OH}$ produced from Fenton's response. Faster disinfection was
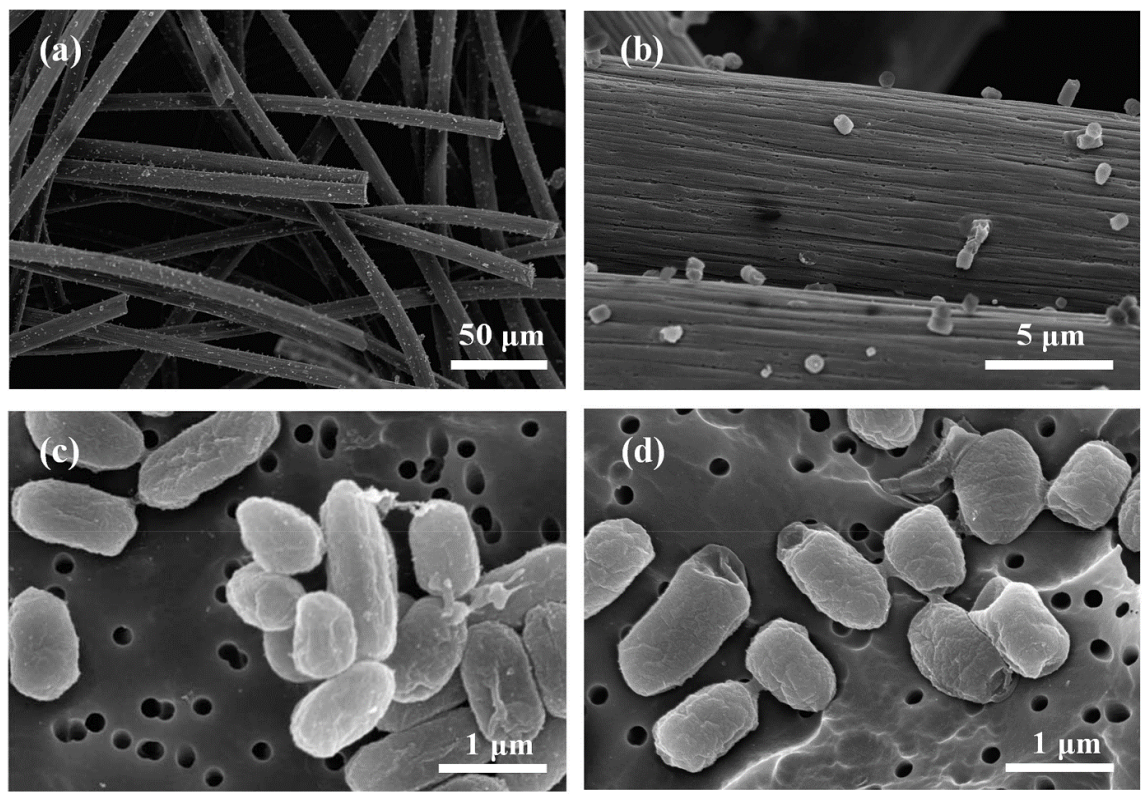

Figure 5. SEM image of the $E$. coli on the G1 fibers and in the water samples. (a) The $E$. coli adsorbed on the G1 fibers at the voltage of $3 \mathrm{~V}$ and flow rate of $30 \mathrm{~mL} / \mathrm{min}$ under $450 \times$ magnification. (b) The E. coli adsorbed on the G1 fiber at the voltage of $3 \mathrm{~V}$ and flow rate of $30 \mathrm{~mL} / \mathrm{min}$ under $6000 \times$ magnification. (c) The morphology of live E. coli in the influent sample under 25,000 $\times$ magnification. (d) The morphology of dead E. coli in the effluent sample after $3 \mathrm{~V}, 30 \mathrm{~mL} / \mathrm{min}$ treatment using G1 as the electrode under 25,000 $\times$ magnification [61]. 
detected for the secondary effluent thanks to its smaller TOC content, letting the attack of bigger amounts of electrogenerated oxidants on microbes. Disinfecting wastewater via $\mathrm{EF}$ was also possible at $\mathrm{pH} \sim 7$, depicting identical removal of active pathogens as a result of the interactive action of produced oxidants such as active chlorine and coagulation with iron hydroxides. A consecutive EC/EF treatment (30 min each) was more efficient for integrated decontamination and disinfection of domestic wastewater (Figure 6).

\section{Cathodic Hydrogen Peroxide Production for Reducing Chlorinated By-Products Generation}

Yao et al. [71] studied the generation of chlorinated by-products throughout surface water treatment via a freshly developed electrochemical advanced oxidation process, the electroperoxone (E-peroxone) process, which combines ozonation with in situ electro-generation of hydrogen peroxide $\left(\mathrm{H}_{2} \mathrm{O}_{2}\right)$ from cathodic

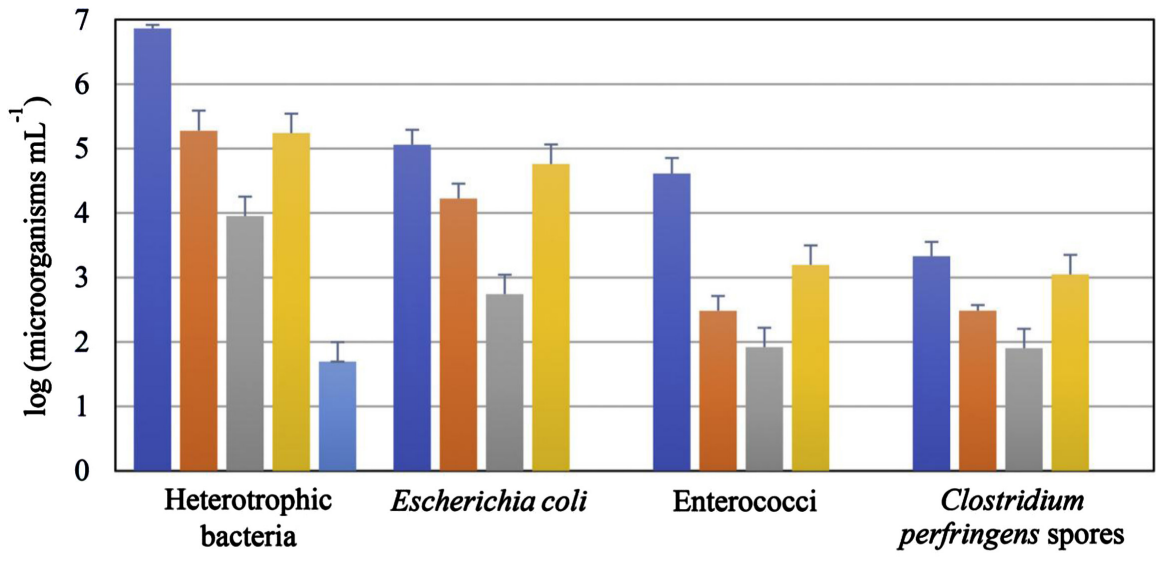

(a)

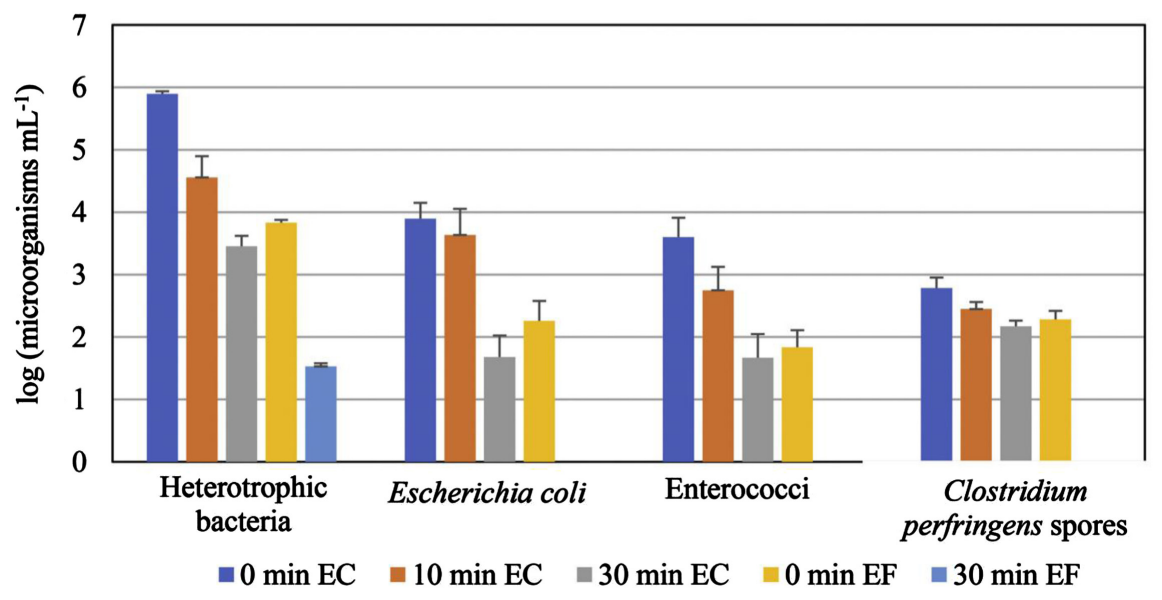

(b)

Figure 6. Change of the logarithm of the concentration of the microorganisms upon sequential EC/EF treatment (30 min each). The EC step was applied to $200 \mathrm{~mL}$ of (a) primary and (b) secondary effluents at $j=200 \mathrm{~A} / \mathrm{m}^{2}$ and $25^{\circ} \mathrm{C}$, being followed by the EF step with $100 \mathrm{~mL}$ of the resulting solution, at $\mathrm{pH} \sim 7$ and $j=333 \mathrm{~A} / \mathrm{m}^{2}$ [62]. 
oxygen reduction (Figure 7). Thanks to the improved ozone $\left(\mathrm{O}_{3}\right)$ transformation to hydroxyl radicals $\left({ }^{\bullet} \mathrm{OH}\right)$ by electro-generated $\mathrm{H}_{2} \mathrm{O}_{2}$, the E-peroxone process greatly increased the removal of ozone-refractory micropollutants like clofibric acid and chloramphenicol in the selected surface water juxtaposed to traditional ozonation. Further, the cathodically produced $\mathrm{H}_{2} \mathrm{O}_{2}$ efficiently quenched hypochlorous acid ( $\mathrm{HOCl}$ ) derived from the anodic oxidation of chloride in the surface water. Consequently, the generation of trichloromethane (TCM) and chloroacetic acids (CAAs) from the responses of $\mathrm{HOCl}$ with dissolved organic matter (DOM) was negligible throughout the E-peroxone process, and identical concentrations of TCM and CAAs were usually detected in the traditional ozonation and E-peroxone treated water. In contrast, important quantities of $\mathrm{HOCl}$ could be formed from the anodic oxidation of chloride and then accumulated in the surface water throughout the traditional electrolysis process, which conducted to considerably bigger levels of TCM and CAAs in the electrolysis treated water. The findings of such research propose that the E-peroxone process could overtake the main barrier of classical electrochemical techniques and furnish an efficacious and secure EAOP option for micropollutant removal during water treatment.

\section{Conclusions}

From this work, the main conclusions emerge:

1) Generation of chlorate and perchlorates throughout electrodisinfection could be avoided with the usage of cells with very low contact time between the water and the electrode and a single-pass strategy. This is explained by the fact that further oxidation of hypochlorite to chlorates and perchlorates could only happen by the direct reaction of hydroxyl radicals which takes place mostly in the close proximity to the anodes [1]. Via connecting cells in series, the disinfection obtained could be augmented and more than 8-logs have been reached [1]. In any case the $N / N_{0}$ follows the same decay trend with respect to the current charge passed regardless of the number of cells attached. Even increasing residence

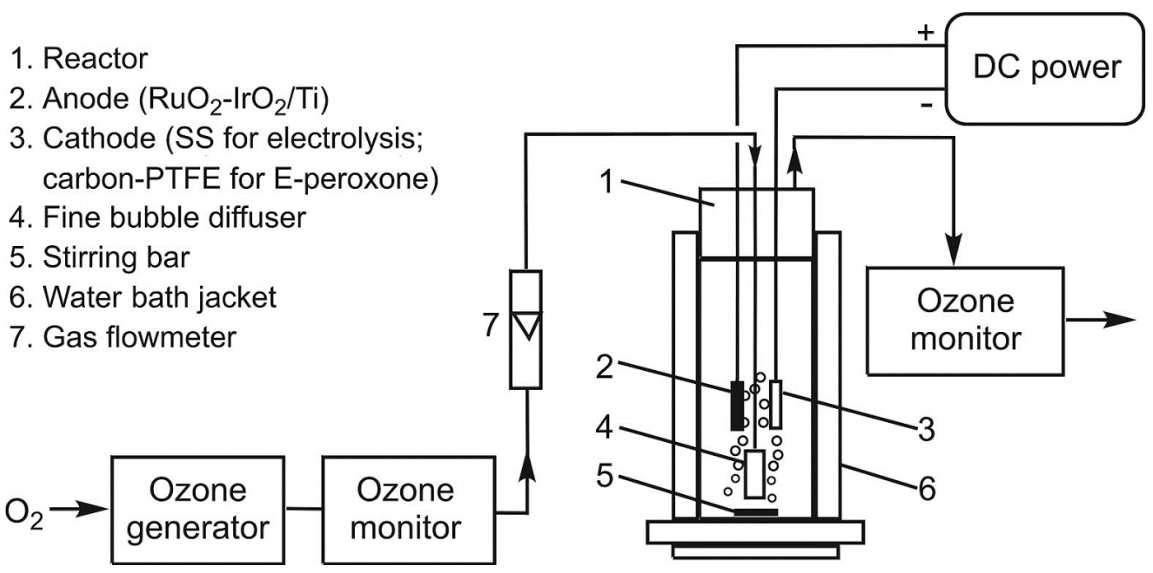

Figure 7. Schematic of the reactor used for electrolysis, conventional ozonation, and the E-peroxone process [71]. 
time four-fold, the concentration of chlorates is very low and close to the detection limit of the analytical technique used.

2) Employing a $\mathrm{Ti} / \mathrm{IrO}_{2}$ anode was efficient for disinfecting aqueduct water. The disinfection rate corresponded to the applied current density. Concerning the specific charge passed, the highest current density $\left(8 \mathrm{~mA} / \mathrm{cm}^{2}\right)$ depicted the greatest rate of disinfection; this corresponded to the increased levels of active chlorine formation in the highest current density tests. Nevertheless, DBPs generation and energy consumption related to the highest current density were bigger than the lower current densities for a specific degree of disinfection. Efficient disinfection without regulatory exceedances in some DBPs could be reached employing a $\mathrm{Ti} / \mathrm{IrO}_{2}$ anode for handling surface water [36].

3) Electrochemical engineering possesses the capacity to become a so crucial technology for dealing with almost any type of contaminated water. It is a strong method for killing pathogens and decomposing toxic and recalcitrant organics. Nevertheless, electrochemical methods stay on the edge of industrial and commercial breakthrough, and more comprehension on the complicated chemistry in the cell and the engineering perspectives in designing and optimizing an electrochemical treatment unit are required before the technique could be viewed as a mature and ready applicable treatment solution [55]. Nanotechnologies could be merged with electrochemical processes for better efficiency in dealing with pathogens and pollutants removal. Separately, both technologies have shown their efficiency in eliminating microorganisms and degrading organic and inorganic contaminants. In the next future, a hybrid process combining both techniques would be suggested as a part of treatment train for treating water and wastewater [72]. On the other hand, the technique of adsorption and electrochemical regeneration employing the graphite intercalation compound (GIC) adsorbents was observed to be efficient in reducing several bacteria $(P$. aeruginosa, $S$. aureus and $L$. pneumoph), fungi, and yeasts. The aptness of the method was also estimated for the fungal species $A$. awamori. Further, the technique was also discovered to be performant in disinfecting yeasts comprising $S$. cerevisiae and $R$. turoloides. However, the disinfection of $C$. parvum via adsorption and electrochemical regeneration employing the GIC adsorbent was not depicted successfully. In this context, an early examination concerning $C$. parvum proposes that using a chloride-free solution in the cathode compartment and a comparatively high current density can be efficacious [73].

\section{Acknowledgements}

This research has been funded by the Research Deanship of University of Ha'il, Saudi Arabia, through the Project RG-191190.

\section{Conflicts of Interest}

The authors declare no conflicts of interest regarding the publication of this paper. 


\section{References}

[1] Isidro, J., Brackemeyer, D., Sáez, C., Llanos, J., Lobato, J., Cañizares, P., Matthée, T. and Rodrigo, M.A. (2020) How to Avoid the Formation of Hazardous Chlorates and Perchlorates during Electro-Disinfection with Diamond Anodes? Journal of Environmental Management, 265, Article ID: 110566. https://doi.org/10.1016/j.jenvman.2020.110566

[2] Ghernaout, D., Naceur, M.W. and Aouabed, A. (2011) On the Dependence of Chlorine By-Products Generated Species Formation of the Electrode Material and Applied Charge during Electrochemical Water Treatment. Desalination, 270, 9-22. https://doi.org/10.1016/j.desal.2011.01.010

[3] Ghernaout, D., Ghernaout, B. and Naceur, M.W. (2011) Embodying the Chemical Water Treatment in the Green Chemistry: A Review. Desalination, 271, 1-10. https://doi.org/10.1016/j.desal.2011.01.032

[4] Ghernaout, D., Elboughdiri, N., Ghareba, S. and Salih, A. (2020) Electrochemical Advanced Oxidation Processes (EAOPs) for Disinfecting Water-Fresh Perspectives. Open Access Library Journal, 7, e6257. https://doi.org/10.4236/oalib.1106257

[5] Ghernaout, D., Benblidia, C. and Khemici, F. (2015) Microalgae Removal from Ghrib Dam (Ain Defla, Algeria) Water by Electroflotation Using Stainless Steel Electrodes. Desalination and Water Treatment, 54, 3328-3337.

https://doi.org/10.1080/19443994.2014.907749

[6] Ghernaout, D., Alghamdi, A. and Ghernaout, B. (2019) Microorganisms' Killing: Chemical Disinfection vs. Electrodisinfection. Applied Engineering, 3, 13-19.

[7] Ghernaout, D. and Ghernaout, B. (2010) From Chemical Disinfection to Electrodisinfection: The Obligatory Itinerary? Desalination and Water Treatment, 16, 156-175. https://doi.org/10.5004/dwt.2010.1085

[8] Ghernaout, D., Badis, A., Ghernaout, B. and Kellil, A. (2008) Application of Electrocoagulation in Escherichia coli Culture and Two Surface Waters. Desalination, 219, 118-125. https://doi.org/10.1016/j.desal.2007.05.010

[9] Ghernaout, D. (2017) Microorganisms' Electrochemical Disinfection Phenomena. EC Microbiology, 9, 160-169.

[10] Ghernaout, D. (2019) Electrocoagulation Process for Microalgal Biotechnology-A Review. Applied Engineering, 3, 85-94.

[11] Ghernaout, D. (2019) Greening Electrocoagulation Process for Disinfecting Water. Applied Engineering, 3, 27-31.

[12] Ghernaout, D. (2019) Electrocoagulation and Electrooxidation for Disinfecting Water: New Breakthroughs and Implied Mechanisms. Applied Engineering, 3, 125-133.

[13] Ghernaout, D. and Elboughdiri, N. (2019) Electrocoagulation Process Intensification for Disinfecting Water-A Review. Applied Engineering, 3, 140-147.

[14] Ghernaout, D. and Elboughdiri, N. (2019) Iron Electrocoagulation Process for Disinfecting Water-A Review. Applied Engineering, 3, 154-158.

[15] Ghernaout, D. (2019) Disinfection via Electrocoagulation Process: Implied Mechanisms and Future Tendencies. EC Microbiology, 15, 79-90.

[16] Ghernaout, D. and Elboughdiri, N. (2019) Mechanistic Insight into Disinfection Using Ferrate(VI). Open Access Library Journal, 6, e5946.

https://doi.org/10.4236/oalib.1105946

[17] Belhout, D., Ghernaout, D., Djezzar-Douakh, S. and Kellil, A. (2010) Electrocoagu- 
lation of a Raw Water of Ghrib Dam (Algeria) in Batch Using Iron Electrodes. Desalination and Water Treatment, 16, 1-9. https://doi.org/10.5004/dwt.2010.1081

[18] Henquin, E.R., Colli, A.N., Bergmann, M.E.H. and Bisang, J.M. (2013) Characterization of a Bipolar Parallel-Plate Electrochemical Reactor for Water Disinfection Using Low Conductivity Drinking Water. Chemical Engineering and Processing, 65, 45-52. https://doi.org/10.1016/j.cep.2012.12.007

[19] Zanin, H., Teofilo, R.F., Peterlevitz, A.C., Oliveira, U., de Paiva, J.C., Ceragioli, H.J., Reis, E.L. and Baranauskas, V. (2013) Diamond Cylindrical Anodes for Electrochemical Treatment of Persistent Compounds in Aqueous Solution. Journal of Applied Electrochemistry, 43, 323-330. https://doi.org/10.1007/s10800-012-0491-4

[20] Ghernaout, D. and Elboughdiri, N. (2020) Disinfection By-Products: Presence and Elimination in Drinking Water. Open Access Library Journal, 7, e6140.

https://doi.org/10.4236/oalib.1106140

[21] Ghernaout, D. and Elboughdiri, N. (2020) Electrocoagulation Process in the Context of Disinfection Mechanism. Open Access Library Journal, 7, e6083.

[22] Ghernaout, D. and Elboughdiri, N. (2020) Strategies for Reducing Disinfection By-Products Formation during Electrocoagulation. Open Access Library Journal, 7, e6076. https://doi.org/10.4236/oalib.1106076

[23] Ghernaout, D. and Elboughdiri, N. (2020) Electrochemical Technology for Wastewater Treatment: Dares and Trends. Open Access Library Journal, 7, e6020.

[24] Ghernaout, D. (2018) Disinfection and DBPs Removal in Drinking Water Treatment: A Perspective for a Green Technology. International Journal of Advances in Applied Sciences, 5, 108-117. https://doi.org/10.21833/ijaas.2018.02.018

[25] Cano, A., Barrera, C., Cotillas, S., Llanos, J., Canizares, P. and Rodrigo, M.A. (2016) Use of DiaCell Modules for the Electro-Disinfection of Secondary-Treated Wastewater with Diamond Anodes. Chemical Engineering Journal, 306, 433-440. https://doi.org/10.1016/j.cej.2016.07.090

[26] Ghernaout, D. and Elboughdiri, N. (2019) Water Disinfection: Ferrate(VI) as the Greenest Chemical-A Review. Applied Engineering, 3, 171-180.

[27] Ghernaout, D. (2019) Virus Removal by Electrocoagulation and Electrooxidation: New Findings and Future Trends. Journal of Environmental Science and Allied Research, 2019, 85-90. https://doi.org/10.29199/2637-7063/ESAR-202024

[28] Ghernaout, D., Aichouni, M. and Touahmia, M. (2019) Mechanistic Insight into Disinfection by Electrocoagulation-A Review. Desalination and Water Treatment, 141, 68-81. https://doi.org/10.5004/dwt.2019.23457

[29] Ghernaout, D., Touahmia, M. and Aichouni, M. (2019) Disinfecting Water: Electrocoagulation as an Efficient Process. Applied Engineering, 3, 1-12.

[30] Ghernaout, D. (2018) Electrocoagulation Process: Achievements and Green Perspectives. Colloid and Surface Science, 3, 1-5. https://doi.org/10.11648/j.css.20180301.11

[31] Ghernaout, D., Alghamdi, A., Aichouni, M. and Touahmia, M. (2018) The Lethal Water Tri-Therapy: Chlorine, Alum, and Polyelectrolyte. World Journal of Applied Chemistry, 3, 65-71. https://doi.org/10.11648/j.wjac.20180302.14

[32] Ghernaout, D. and Elboughdiri, N. (2020) Is Not It Time to Stop Using Chlorine for Treating Water? Open Access Library Journal, 7, e6007.

[33] Ghernaout, D., Moulay, S., Ait Messaoudene, N., Aichouni, M., Naceur, M.W. and Boucherit, A. (2014) Coagulation and Chlorination of NOM and Algae in Water Treatment: A Review. International Journal of Environmental Monitoring and 
Analysis, 2, 23-34. https://doi.org/10.11648/j.ijema.s.2014020601.14

[34] Ghernaout, D. (2017) Water Treatment Chlorination: An Updated Mechanistic Insight Review. Chemistry Research Journal, 2, 125-138.

[35] Bruguera-Casamada, C., Sires, I., Brillas, E. and Araujo, R.M. (2017) Effect of Electrogenerated Hydroxyl Radicals, Active Chlorine and Organic Matter on the Electrochemical Inactivation of Pseudomonas aeruginosa Using BDD and Dimensionally Stable Anodes. Separation and Purification Technology, 178, 224-231. https://doi.org/10.1016/j.seppur.2017.01.042

[36] Schaefer, C.E., Andaya, C. and Urtiaga, A. (2015) Assessment of Disinfection and By-Product Formation during Electrochemical Treatment of Surface Water Using a $\mathrm{Ti} / \mathrm{IrO}_{2}$ Anode. Chemical Engineering Journal, 264, 411-416. https://doi.org/10.1016/j.cej.2014.11.082

[37] Li, Y., Kemper, J.M., Datuin, G., Akey, A., Mitch, W.A. and Luthy, R.G. (2016) Reductive Dehalogenation of Disinfection Byproducts by an Activated Carbon-Based Electrode System. Water Research, 98, 354-362.

https://doi.org/10.1016/j.watres.2016.04.019

[38] Ghernaout, D. and Elboughdiri, N. (2020) Controlling Disinfection By-Products Formation in Rainwater: Technologies and Trends. Open Access Library Journal, 7, e6162. https://doi.org/10.4236/oalib.1106162

[39] Ghernaout, D. and Elboughdiri, N. (2020) Towards Enhancing Ozone Diffusion for Water Disinfection-Short Notes. Open Access Library Journal, 7, e6253. https://doi.org/10.4236/oalib.1106253

[40] Boucherit, A., Moulay, S., Ghernaout, D., Al-Ghonamy, A.I., Ghernaout, B., Naceur, M.W., Ait Messaoudene, N., Aichouni, M., Mahjoubi, A.A. and Elboughdiri, N.A. (2015) New Trends in Disinfection By-Products Formation upon Water Treatment. Journal of Research \& Developments in Chemistry, 2015, Article ID: 628833.

[41] Ghernaout, D., Elboughdiri, N., Ghareba, S. and Salih, A. (2020) Disinfecting Water with the Carbon Fiber-Based Flow-Through Electrode System (FES): Towards Axial Dispersion and Velocity Profile. Open Access Library Journal, 7, e6238. https://doi.org/10.4236/oalib.1106238

[42] Ghernaout, D. (2017) Environmental Principles in the Holy Koran and the Sayings of the Prophet Muhammad. American Journal of Environmental Protection, 6, 75-79. https://doi.org/10.11648/j.ajep.20170603.13

[43] Ghernaout, D. and Naceur, M.W. (2011) Ferrate(VI): In Situ Generation and Water Treatment-A Review. Desalination and Water Treatment, 30, 319-332. https://doi.org/10.5004/dwt.2011.2217

[44] Ghernaout, D., Elboughdiri, N. and Ghareba, S. (2020) Fenton Technology for Wastewater Treatment: Dares and Trends. Open Access Library Journal, 7, e6045. https://doi.org/10.4236/oalib.1106045

[45] Ghernaout, D. and Elboughdiri, N. (2020) Advanced Oxidation Processes for Wastewater Treatment: Facts and Future Trends. Open Access Library Journal, 7, e6139. https://doi.org/10.4236/oalib.1106139

[46] Ghernaout, D. (2013) Advanced Oxidation Phenomena in Electrocoagulation Process: A Myth or a Reality? Desalination and Water Treatment, 51, 7536-7554. https://doi.org/10.1080/19443994.2013.792520

[47] Julio, F.R., Hilario, T.-P., Mabel, V.M., Raymundo, L.C., Arturo, L.-R. and Neftal, R.-V.M. (2015) Disinfection of an Advanced Primary Effluent Using Peracetic Acid or Ultraviolet Radiation for Its Reuse in Public Services. Journal of Water and Health, 13, 118-124. https://doi.org/10.2166/wh.2014.028 
[48] Rajab, M., Heim, C., Letzel, T., Drewes, J.E. and Helmreich, B. (2015) Electrochemical Disinfection Using Boron-Doped Diamond Electrode-The Synergetic Effects of in Situ Ozone and Free Chlorine Generation. Chemosphere, 121, 47-53. https://doi.org/10.1016/j.chemosphere.2014.10.075

[49] Valero, P., Verbel, M., Silva-Agredo, J., Mosteo, R., Ormad, M.P. and Torres-Palma, R.A. (2017) Electrochemical Advanced Oxidation Processes for Staphylococcus aureus Disinfection in Municipal WWTP Effluents. Journal of Environmental Management, 198, 256-265. https://doi.org/10.1016/j.jenvman.2017.04.070

[50] Ghernaout, D. and Elboughdiri, N. (2020) UV-C/ $/ \mathrm{H}_{2} \mathrm{O}_{2}$ and Sunlight $/ \mathrm{H}_{2} \mathrm{O}_{2}$ in the Core of the Best Available Technologies for Dealing with Present Dares in Domestic Wastewater Reuse. Open Access Library Journal, 7, e6161. https://doi.org/10.4236/oalib.1106161

[51] Ghernaout, D., Laribi, C., Alghamdi, A., Ghernaout, B., Ait Messaoudene, N. and Aichouni, M. (2018) Decolorization of BF Cibacete Blue (CB) and Red Solophenyle 3BL (RS) Using Aluminum Sulfate and Ferric Chloride. World Journal of Applied Chemistry, 3, 32-40. https://doi.org/10.11648/j.wjac.20180302.11

[52] Ghernaout, D. and Ghernaout, B. (2011) On the Controversial Effect of Sodium Sulphate as Supporting Electrolyte on Electrocoagulation Process: A Review. Desalination and Water Treatment, 27, 243-254. https://doi.org/10.5004/dwt.2011.1983

[53] Rahmani, A.R., Samarghandi, M.R., Nematollahi, D. and Zamani, F. (2019) A Comprehensive Study of Electrochemical Disinfection of Water Using Direct and Indirect Oxidation Processes. Journal of Environmental Chemical Engineering, 7, Article ID: 102785. https://doi.org/10.1016/j.jece.2018.11.030

[54] Jung, Y.J., Baek, K.W., Oh, B.S. and Kang, J.-W. (2010) An Investigation of the Formation of Chlorate and Perchlorate during Electrolysis Using Pt/Ti Electrodes: The Effects of $\mathrm{pH}$ and Reactive Oxygen Species and the Results of Kinetic Studies. Water Research, 44, 5345-5355. https://doi.org/10.1016/j.watres.2010.06.029

[55] Muff, J. (2014) Electrochemical Oxidation-A Versatile Technique for Aqueous Organic Contaminant Degradation. In: Chemistry of Advanced Environmental Purification Processes of Water, Elsevier B.V., Amsterdam, Ch. 3. https://doi.org/10.1016/B978-0-444-53178-0.00003-1

[56] Liu, K., Bai, L., Shi, Y., Wei, Z., Spinney, R., Göktaş, R.K., Dionysiou, D.D. and Xiao, R.R. (2020) Simultaneous Disinfection of E. faecalis and Degradation of Carbamazepine by Sulfate Radicals: An Experimental and Modelling Study. Environmental Pollution. https://doi.org/10.1016/j.envpol.2020.114558

[57] Ojha, A. (2020) Nanomaterials for Removal of Waterborne Pathogens: Opportunities and Challenges. In: Waterborne Pathogens, Elsevier Ltd., Amsterdam, Ch. 19. https://doi.org/10.1016/B978-0-12-818783-8.00019-0

[58] Ghernaout, D. and Elboughdiri, N. (2020) Antibiotics Resistance in Water Mediums: Background, Facts, and Trends. Applied Engineering, 4, 1-6. https://doi.org/10.4236/oalib.1106003

[59] Ghernaout, D. and Elboughdiri, N. (2020) Removing Antibiotic-Resistant Bacteria (ARB) Carrying Genes (ARGs): Challenges and Future Trends. Open Access Library Journal, 7, e6003. https://doi.org/10.4236/oalib.1106003

[60] Ghernaout, D. and Elboughdiri, N. (2020) Should We Forbid the Consumption of Antibiotics to Stop the Spread of Resistances in Nature? Open Access Library Journal, 7, e6138.

[61] Ni, X.-Y., Liu, H., Wang, C., Wang, W.-L., Xu, Z.-B., Chen, Z., Wu, Y.-H. and Hu, H.-Y. (2020) Comparison of Carbonized and Graphitized Carbon Fiber Electrodes 
under Flow-Through Electrode System (FES) for High-Efficiency Bacterial Inactivation. Water Research, 168, Article ID: 115150.

https://doi.org/10.1016/j.watres.2019.115150

[62] Anfruns-Estrada, E., Bruguera-Casamada, C., Salvadó, H., Brillas, E., Sirés, I. and Araujo, R.M. (2017) Inactivation of Microbiota from Urban Wastewater by Single and Sequential Electrocoagulation and Electro-Fenton Treatments. Water Research, 126, 450-459. https://doi.org/10.1016/j.watres.2017.09.056

[63] Ghernaout, D., Alghamdi, A. and Ghernaout, B. (2019) Electrocoagulation Process: A Mechanistic Review at the Dawn of Its Modeling. Journal of Environmental Science and Allied Research, 2, 51-67. https://doi.org/10.29199/2637-7063/ESAR-201019

[64] Irki, S., Ghernaout, D., Naceur, M.W., Alghamdi, A. and Aichouni, M. (2018) Decolorizing Methyl Orange by Fe-Electrocoagulation Process-A Mechanistic Insight. International Journal of Environmental Chemistry, 2, 18-28. https://doi.org/10.11648/j.ijec.20180201.14

[65] Irki, S., Ghernaout, D., Naceur, M.W., Alghamdi, A. and Aichouni, M. (2018) Decolorization of Methyl Orange (MO) by Electrocoagulation (EC) Using Iron Electrodes under a Magnetic Field (MF). II. Effect of Connection Mode. World Journal of Applied Chemistry, 3, 56-64. https://doi.org/10.11648/j.wjac.20180302.13

[66] Irki, S., Ghernaout, D. and Naceur, M.W. (2017) Decolourization of Methyl Orange (MO) by Electrocoagulation (EC) Using Iron Electrodes under a Magnetic Field (MF). Desalination and Water Treatment, 79, 368-377. https://doi.org/10.5004/dwt.2017.20797

[67] Ghernaout, D., Al-Ghonamy, A.I., Ait Messaoudene, N., Aichouni, M., Naceur, M.W., Benchelighem, F.Z. and Boucherit, A. (2015) Electrocoagulation of Direct Brown 2 (DB) and BF Cibacete Blue (CB) Using Aluminum Electrodes. Separation Science and Technology, 50, 1413-1420. https://doi.org/10.1080/01496395.2014.982763

[68] Ghernaout, D. and Ghernaout, B. (2012) Sweep Flocculation as a Second Form of Charge Neutralisation-A Review. Desalination and Water Treatment, 44, 15-28. https://doi.org/10.1080/19443994.2012.691699

[69] Ghernaout, B., Ghernaout, D. and Saiba, A. (2010) Algae and Cyanotoxins Removal by Coagulation/Flocculation: A Review. Desalination and Water Treatment, 20, 133-143. https://doi.org/10.5004/dwt.2010.1202

[70] Ghernaout, D., Elboughdiri, N., Ghareba, S. and Salih, A. (2020) Coagulation Process for Removing Algae and Algal Organic Matter-An Overview. Open Access Library Journal, 7, e6272. https://doi.org/10.4236/oalib.1106272

[71] Yao, W., Fu, J., Yang, H., Yu, G. and Wang, Y. (2019) The Beneficial Effect of Cathodic Hydrogen Peroxide Generation on Mitigating Chlorinated By-Product Formation during Water Treatment by an Electro-Peroxone Process. Water Research, 157, 209-217. https://doi.org/10.1016/j.watres.2019.03.049

[72] Ghernaout, D. and Elboughdiri, N. (2020) On the Treatment Trains for Municipal Wastewater Reuse for Irrigation. Open Access Library Journal, 7, e6088. https://doi.org/10.4236/oalib.1106088

[73] Hussain, S.N., Trzcinski, A.P., Asghar, H.M.A., Sattar, H., Brown, N.W. and Roberts, E.P.L. (2016) Disinfection Performance of Adsorption Using Graphite Adsorbent Coupled with Electrochemical Regeneration for Various Microorganisms Present in Water. Journal of Industrial and Engineering Chemistry, 44, 216-225. https://doi.org/10.1016/j.jiec.2016.09.009 